Die Lokalisation zeigte das bekannte Verteilungsmuster mit Bevorzugung der Steißbeingegend in 22 Fällen, gefolgt von den Mediastinalteratomen in 10 Fällen, den Hodenteratomen in 6 Fällen, den Ovarialteratomen in 2 Fällen.

Die Altersverteilung ließ mit 82,2\% (37 Fälle) eine Prädilektion des Säuglingsund Kleinkindesalters erkennen. Allein $48 \%$ der Teratome fielen in das 1 . Lebensjahr. Neben der Radikaloperation wurde bei malignen Teratomen in 6 Fällen noch eine Bestrahlungsbehandlung und cytostatische Therapie durchgeführt, die jedoch ohne Effekt war.

Die Prognose der benignen Teratome ist gut. Von 33 benignen Tumoren starben 3 Kinder $(10 \%)$, von denen 2 an einer heute vermeidbaren postoperativen Hyperpyrexie in den Jahren 1952/53 ad finem kamen.

Die Utberlebenschance der malignen Teratome ist gering, die Prognose ist fast in allen Fällen infaust. Von 12 malignen Teratome starben 9 bei einer Utberlebenszeit von 1-6 Monaten. 3 maligne Hodenteratome überlebten alle, und zwar 41/2, 14 und 18 Jahre nach dem Eingriff. Eine Verbesserung der Ergebnisse kann nur von einer Frühdiagnose und frühzeitigen operativen Behandlung erwartet werden.

\title{
35. Operationsindikation und Prognose intrathorakaler Tumoren im Säuglings- und Kindesalter
}

\section{REgensbuRGer-Göttingen}

\section{Indications for Operation and Prognosis in Thoratic Tumours of Infants and Children}

Summary. After an enumeration of the difficulties and problems in the diagnosis of benign and malignant intrathoracic tumours in infancy and childhood the indication for operative treatment, present in nearly all cases, is discussed. 29 cases are reported who were admitted for operative treatment in the past 15 years. The long period of observation after operation in the majority of children makes it possible to express an opinion on the prognosis of the various tumours.

Zusammenfassung. Nach Aufzeigen der Schwierigkeiten und Problematik bei der Diagnostik intrathorakaler benigner und maligner Tumoren im Säuglingsalter und Kindesalter, wird die Indikation zur operativen Behandlung, die in fast allen Fällen besteht, diskutiert. Es wird über 29 Tumoren berichtet, die im Laufe der letzten 15 Jahre zur operativen Behandlung eingewiesen wurden. Die lange Verlaufsbeobachtung bei der Mehrzahl der operierten Kinder erlaubt es, auch zur Prognose der verschiedenen Tumoren Stellung zu nehmen.

\section{Die malignen Thoraxtumoren im Kindesalter}

\section{F. Helmer, L. Howantetz* und G. WhissendBacher-Wien/Öterreich}

\section{Malignant Thoracic Tumours in Children}

Summary. In contrast to the many heroic attempts, which have been madeespecially in the United States-to remove tumours as radically as possible by means of surgery lasting many hours and causing considerable damage to the 